\title{
TECHNOLOGIES IN THE CLASSROOM: REFLECTING ABOUT TEACHING, RESEARCH AND EXTENSION ON PUBLIC SCHOOLS OF RIO GRANDE DO NORTE, BRAZIL
}

\author{
Elizama das Chagas Lemos ${ }^{1}$, Ilane Ferreira Cavalcante ${ }^{2}$, Thalita Cunha Motta ${ }^{3}$ \\ ${ }^{1}$ Postgraduate teacher andMaster in Systems and Computing, Campus Educação a Distância, IFRN, Natal, Brasil \\ ${ }^{2}$ Postgraduate teacher and Doctor of Education, Campus Educação a Distância, IFRN, Natal, Brasil \\ ${ }^{3}$ Postgraduate teacher and Doctor of Education, Campus Educação a Distância, IFRN, Natal, Brasil
}

\begin{abstract}
This paper relates some results reached throughout two integrated projects (one extension project and a research) developed in 2017 by the research group of Multireference, education and language (GPMEL) from Campus of Distance Education at Federal Institute of Education, Science and Technology of RN (IFRN). These projects were developed in cooperation with two public schools in Natal and Parnamirim (RN): JoãoTibúrcio State School and Brigadeiro Eduardo Gomes City School. Sancho [11] was the basis to the analysis of the teachers'view about the school they work. In the extension project it was offered a on line course about technologies in the classroom, while in the research we investigated, using a questionnaire, how the same teachers use technologies in the classroom and the technological support they have to work in the schools.
\end{abstract}

Keywords: - collaborative work, distance education, extension and research, Technologies of information and communication.

\section{THE TECHNOLOGIES TO THE EDUCATION}

\section{THAT WE WANT}

Many authors, such as Morin [9] and Kenski[6] discuss how technologies may be used to improve a better work for teachers. There are many ways to use Technologies in teachers' daily work, it can be used to improve technological innovation, to diversify the work in and outside the school walls, or as a tool to collaborate in the educational process, helping to plan, to prepare classes and to formulate evaluation instruments, reports and feedbacks.

There are also many theories, forms and platforms that affirm that the technological mediation is able to help in blended learning and in flipped classrooms. Authors such as Rojo[10] and Mercado [8] point out the need to update methodologies, to promote teachers' upgrade and training, and to adapt educational environments, taking them out of the traditional and old-fashioned "transference of knowledge".

Rojo[10] mentions that to use new educational environments it is necessary to improve new kinds of literacy, paying attention to different tools that emerge from these virtual environments, such as hypertexts, hypermedia, that demand flexibility and collaborative work.

Mercado and Gonçalves[8] remember that the last decades in Brazil demanded great changes to turn school into a place that helps to develop the learning to learn ability. But this turned to be a very difficult challenge for many reasons: lack of infrastructure, no teacher training, old-fashioned political and pedagogical projects are a few of examples.

Sancho [11] presents seven axioms to convert the Technologies of Information and Communication (TIC) in triggers to technological innovation, transcending the teacher. Though this has been something debated for the last decades, it is still a very updated discussion. The theories transit from the obvious need to a technological structure that helps teachers to a very "out of the box" idea of classroom, based on constructivist ideas, for instance. After all, the teacher may be trained, have innovative ideas to change his/her methodology, but, if the institution does not allow his work, does not offer the proper facility, and does not approve the teacher's ideas, things tend to fail.

There are other realities that give support to the barriers of the teaching work: few time to planning and to training, for example. Brazilian teacher faces one of the less attractive salaries of the category in the world, so he/she needs to work on two or three schools to earn a little more. Time to make courses, or to plan classes are not always counted on his hours at work, even on public schools. And when they are counted, are not enough. So it is important not to blame on their apparent lack of interest in using innovative methodologies or technologies. This work only tries to investigate and understands some aspects of a very complex reality, because it is necessary to think the future of education on a wide view, analyzing the nowadays sceneries on its multidimensional aspects. 
Morin [9] discusses about the education of the future articulating seven principles that need to be part of the human condition, his processes to build knowledge and the forms of education. So it is important to understand human mental, cultural and biological characteristics. He also affirms the importance of technologies to help humanity in the globalization of societies. As the world is living a planetary age, human kind tends to "submerge in the complexity of the world - as uncountable information about the world smother our possibilities of intelligibility" [9]. Telecommunication, the twist of information and the Internet involves everybody nowadays, unifying and deterritorializing the spaces of coexistence, though, as the same author affirms, globalization not only unifies, it also may promote the contrary: balkanization. These are multiple and different aspects of a complex process of development that is not only material, but also intellectual, moral and affectionate. That is how it is possible to understand this rhizomatic and abstruse world, basing our thinking on anthropological, ecologic, civic, earth and spiritual conscience of the human condition.

Parting from this perspective we must think about the use of technologies in the school. One of the elements of this use is the management of spaces and times, because, different from the world wide web, these aspects are more controlled and rigid, and also limited to a quantity of individuals that coexist on a specific space and time when we talk about the traditional model of school. This school also presents a clear hierarchy that controls how the dialogue happens among managers, teachers and students, and also the relative freedom that teachers have to perform, according to previously established contents that must be seen in the classroom, as well as according to the institutional political and pedagogical project.

The Internet is built to perform on a very flexible and wide time and space, connecting almost an infinite quantity of individuals. There are no hierarchies on their relation, and each one has equal space and time to express his/her thoughts and ideas. There are not, on the other hand, little or any questioning about the quality or the relevance of the content that is shared, and not necessarily a critic reflection about the information that deserves or doesn't deserve to be taken as knowledge. Although, the internet can be a very important tool to the process of learning. The best way to do it is, perhaps, to blend formal and informal, presence and distance education. After all, everything that is produced in society may be useful in the process of learning after a didactic transposition and with the help of a facilitator.

"The didactical transposition processes and, generally, the institutional ones are - we imagine, the essential tool to knowledge, for its dissemination and its proper function [...]. A specific know-how, named $S$, may be found in many types of institutions named $\mathrm{T}$, and, in terms of knowledge ecology, they have several different habitats. In this scenery, the same type of knowledge regularly occupies many kinds of niche, so the relation between these different know-hows and the institutions are also diverse. Concomitantly, the way each institutional agent manipulates this know-how is also variable". [2]

It is clear that each know-how needs to be reallocated to allow that information becomes knowledge throughout didactic transposition. In this process language assumes a substantial role, specially when we talk about the technologies used in education that are sustained by the communication among its users and that request different types of language. When a new technology is created, it comes together with new conflicts as well as with new possible uses to formal education, for they have the most varied purposes, but with a proper transposition, they may be able to enlarge it's use in educational processes. Rojo[10] affirms that "Integration of semeiotic, hypertexts, the guarantee of a space to authorship, the circulation of political discourses on the same cyber space, only a click away, all of this demands new literacy practices on hypermedia. And such digital literacies, or new literacies, do not simple emerge from the development of new technologies. They are related to a new mentality that may, or may not, be realized with the help of new digital technologies."

Virtual tools may be categorized depends on their form or on their contents. The form is connected to its technical resources, such as computer programs and application available on the cloud. The contents are linked to the many uses such resources present, such as potential mechanisms to improve learning [1]. Though, as emphasized, motivation is necessary to the effective use of these tools and the level of development of each individual is also important for it's better use to educational purposes. The technological environments that stimulate interaction need to present a cultural background and must be planned to help to build knowledge.

Therefore, schools have to be able to follow the changes in technologies, applying them to the teaching-researchingextension triad on a satisfactory and contextualized way, based on interpersonal relationships, mutability, collaboration, autonomy, among other aspects.

\section{RESEARCH AND EXTENSION PROJECTS}

\section{AT IFRN}

The Federal Institutes (IF) have as one of its main subjects to develop extension projects according to the principles and purposes of professional and technological education, and articulated to the world of labor and its social segments, detaching production and the spread of scientific and technological knowledge [5]. All this is empowered by the item V, article 7o, Law 11.892/2008.

Interchange with society is practiced in IFRN expecting to articulate the different organs of extension, the different acts of teaching and the research projects, to promote teaching verticalization and, also, equal relationship with internal and 
external communities. These actions need to be brought together with the educational model appointed by the institute in its documents.

Research must be associated to extension in order to legitimize itself as a teaching principle, concentrating new categories and spreading itself on the educational field. Thus, it is necessary to unify research problems and investigation under the guidance of teachers and technicians from IFRN, searching to develop investigative stance in the academic and formative processes inside the institution, especially when they are applicable in education, science and technology. Such articulation, besides promoting integrated formation, also develops human abilities to generate new knowledge [5].

This study presents the junction of two projects developed during 2017: a research and an extension one. The first, Use of technological resources in basic education: analyzing the conception and the use of technologies among public school teachers in $\mathrm{RN}$, intended to know the technological infrastructure of public schools and to understand the teachers' use of technology in their classroom.

The latter, Integrative and collaborative practices with public schools in $R N$ is a collaborative work that takes IFRN's undergraduate students and teachers to public schools of RN with the purpose of offering workshops to the students of these schools and their teachers. This project has been developed over the course of three years, changing the schools every year, as well as it's format, in order to attend to collaborative principles defended by Damiani [4] and to reassure the principles of the IFRN's Political and Pedagogical Project [5]. The adopted methodology is generally based on the offer of different workshops depending on school's needs and interests.

The project is divided in four distinct phases. Firstly, the motivation, is when project's representative visits schools to propagate the purposes of the project to the administrative body and to the teachers. At this moment, the project themes are discussed and also its collaborative methodology, which requests the effective participation of the school's agents. Simultaneously, the contents and the format of each workshop as well as the schedules are negotiated in a way that it can take the most appropriate shape for all.

Back to IFRN, the planning is developed in group, didactical material to the workshop is elaborated and researchers and extension students read and discuss the theories and the methodological procedures that basis the project. When the schedules are adjusted with all the involved schools, the workshops are offered (to teachers and students of each school) using the technological support available. Two workshops were offered to teachers in 2017: Technologies in the classroom and Inclusive education. To the schools' students the workshops were based on specific contents the schools identified as more difficult to students: Personal relationships, Reading and interpretation of texts,
Producing argumentative texts and Environmental education were some of the workshop developed during 2017. To finish the project, an event reunites all the participants, the Pedagogical collaboration encounter between IFRN and Public Schools of RN.

The following topic presents the characterization of the partner schools in 2017, the subjects and the analyzed data based on Sancho [11].

\section{SCHOOLS AND SUBJECTS} CHARACTERIZATION

The extension project was developed in two public schools in the city of Natal and Parnamirim/RN: JoãoTibúrcio State School and Brigadeiro Eduardo Gomes City School. JoãoTibúrcio State School is located in a traditional commercial region in the city of Natal/RN. It was founded in 1935 and its physical infrastructure demonstrates the traces of its history, it is an old construction with extensions that didn't left enough space for the students to recreate, there are not enough areas to it, and the classrooms, placed around the sports court are always suffering the influence of the noise that comes from there. It has only one laboratory of informatics with ten computers available to teachers and students.

Brigadeiro Eduardo Gomes city school is younger, situated in a region of recent urbanization in the city of Parnamirim/RN. The school has different spaces of recreation and even what they called a "literature square" with pallets and cushions fro students to sit, talk, read, etc. The schools are placed around the recreation areas, but there is area enough to difficult disturbance and the sports court is not very close to them. The school also has only one laboratory of informatics that disposes of fifteen computers to teachers and students.

Both schools attend to a socially vulnerable public, though in JoãoTibúrcio school, perhaps for its central location, or commercial area, the vulnerability is more evident, according not only with the responsible for this project, but also with the informal reports of the teachers, that commented on their students daily exposure to violence. They also mentioned that the students come from many different regions of the city, some very distant, what turns them into a very heterogeneous group. The public of the Brigadeiro Eduardo Gomes city school, which is situated in a residential region, is much more homogeneous, though they come from different neighborhoods of the region.

The socioeconomic reality of the students of these two schools maybe demanded a public and free educational transportation, for the public transports they take to go to school cause interference in their routine, such as delays and early leaves. It also would be very important, to students, to count on a specific laboratory that they could use to make their own studies. But the only lab the school presents is always in use and not always maintained. 
There are 15 subjects, 6 from JoãoTibúrcio State School and 9 from Brigadeiro Eduardo Gomes City School, and they have different degree areas, 1 is a Visual Arts teacher, 2 are Biologists, 1 is an accountant, 1 has degrees in Religion and History, 1 is a Physical Educator, 1 is a Geographer, 1 is a Historian, 5 have Letters degree, 1 is a Mathematician and one has a degree in Pedagogy. 1 of the subjects finished a further training course, 6 finished specialization courses and 4 concluded Master degrees. They are all state or municipal servants.

The research and the extension projects developed simultaneously and crossed the teachers (subjects) work through two actions: offering the workshop Technologies in the classroom and the analyzing the teachers 'use of the technologies in their classrooms. Both projects based their actions in Sancho's [11] ideas about the use of educational resources and about the teachers' knowledge.

\section{WORKSHOP: TECHNOLOGIES IN THE}

\section{CLASSROOM}

One of the purposes of the workshop Technologies in the classroom was to reflect about the use of TICs in education and to innovate the teachers' resources and tools. It was a 20 hours workshop focused in some specific technological resources, with only one live moment and the rest of the hours using Moodle platform. Figure 1 shows part of the virtual classroom in the virtual environment.

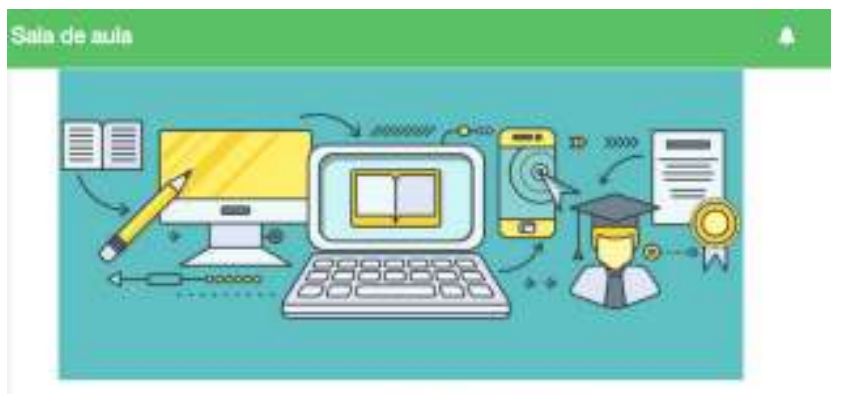

Professora: Elizama Lemos

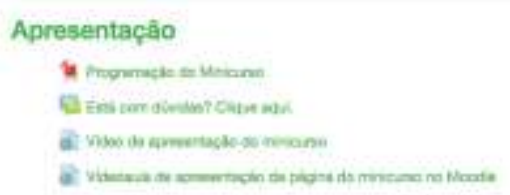

Fig -1: Firstpageofthe workshop Technologies in the classroom.Source: IFRN/MOODLE (2017).

The workshop contents blended theory and practice to reflect about the innovative characters of the TICs, as they may be used to educational purposes and how they may fall into a pedagogical vacuum if they are not used based on an appropriate planning and constant reflection. Beyond this reflection, the teachers involved read Sancho's [11]text that presents seven axioms necessary to convert TIC in triggers to innovation. To put theories in practice, it was used the Plickers app, which is free, and provides dynamical activities to develop with students using only printed cards and a smartphone.

The first week of the workshop was, as we mentioned before, devoted to read the text "From information Technologies to educational resources" by Sancho [11]. The students had to answer a question after reading: "Based on the text, write about the use of TIC on education, pointing out the seven axioms that the author mentions and how they have been developed in the school you work as a teacher. The purpose of this activity was to provoque a reflective thought about their work and the possibilities they have to use technologies innovatively and effectively considering the positive aspects and the obstacles they have in their daily work. Five answers were posted on the platform. Two questioned the infrastructure available to their work and the lack of a constructive view in the management of the schools, which meant an obstacle to the teachers use of technologies. One of the answers reports:

"In relation to the axioms, respecting the first axiom, I believe the schools where I give classes present a high and large connection to internet (WAN). I lived an experience more than three years ago, I asked the principal of the school were I worked if I could use the informatics room if everything was working well. I received a positive answer, but on a total of 12 machines, only three worked and only one had access to the internet, so nobody could really enjoy the class I gave. I went out of the classroom very upset, but I proposed to read narrative texts using the internet, but still nobody enjoyed the classroom. I ended up by contouring the situation using slides about the history of the school that I already had to another class discussing the centenary of the school. As I work in many schools, I believe it is difficult to find schools with good equipment, regularly maintained and updated, as well as to socialize the password so that teachers and students can access internet. In all the schools I work, some expose the password to students and to teachers, other only expose to teachers."

The teacher's report above shows that many schools do not have the minimal structure needed, and when they have, they make it harder to access it, for many reasons, security is one of these reasons, there are only some equipment, maintenance has a high cost, and sometimes nobody knows how to use the equipment, or even, there is no maintenance at all, because there are not technicians to do this. Besides, another barrier is the lacking of training for teachers in order to prepare them to use these equipments, as we can observe on the report below:

"[...] We have some equipment in the schools, though they are not enough to make transformation. We need an appropriate training for the teachers, for these new Technologies, surprisingly, were not added to the daily life of these professionals, their practice is still based on traditional perspectives. This reality confronts possibilities to use Technologies in the classroom. These professionals not always despise these new technological possibilities, but 
they don't know and don't have the necessary abilities to use them."

About the axiom the focus on the constructive approach of the management some of the reports are also interesting, as we point out on the report below, that emphasizes the distance and the resistance of the management, besides their traditional point of view, which diverges from the contemporary context, that demands change:

"Beyond these obstacles faced by the teacher, we verify others with equal importance: the management distance from a constructivist perspective, I mean, a divergence between the social context, the popular culture and the educational projects that evolve the use of TIC, we observe, parting from the pedagogical coordination staff a subtle resistance to new approaches and new conceptions of teaching/learning. We may notice that this staff presents very outdated concepts based on traditionalists practices. To this staff, the student's learning process only takes places in a classroom with desks in line and a white board filled with contents to copy and to be asked later from the students in order to establish the learning results of each discipline separately, I mean, with the bimestrial grades."

Mentioning the student's autonomy in building their own knowledge, there are a few reports also very interesting. Such reports guided a reflection about the use of the search mechanisms and the sources to research in the internet and also a concern about plagiarism. Preparing the teachers to explain to their students how to use network information as a source without plagiarism. The next reports approaches this theme:

"[...] I think a lot in how to give a class where the students acquire their own education. I motivate, in terms of the Freire's autonomy, even using literature, trying to motivate them to live a healthily emotional and intellectual life. [...] One of the aspects I have to agree with is that students don't yet know how to research some contents and do not understand how plagiarism is a crime. I notice that even their argumentative text production are taken from Internet and given to me as they were their own. I believe that it's necessary to do a lot to clear their knowledge about what is acceptable and what is not as their student's tasks."

The workshop second activity also could be made by a couple (as the first one), on a collaborative form, and it asked the teachers to plan a whole week of classrooms using Plickers app on a creative way, realizing a simple quiz or contest, or even an evaluation. To share this experience, the teachers had to post this planning on an appropriate forum on the platform presenting the following elements: classrooms subjects, contents, and instructional resources they wanted to use and the methodology. It was also necessary that the teachers posted a 5-minute video to demonstrate the use of the app. There were five posted activities, with a positive feedback from these teachers and from the students that participated in their classrooms, they said the experience was dynamical and it was a planned use of technology.

To materialize this activity a video class was posted on the platform, explaining, on a simple way, how to use the app. Up to that moment, there was not enough material on the cloud about this theme in Portuguese to share with those teachers in training, so it was necessary to produce didactic material. This material was posted on open access and presented a considerable number of accesses.

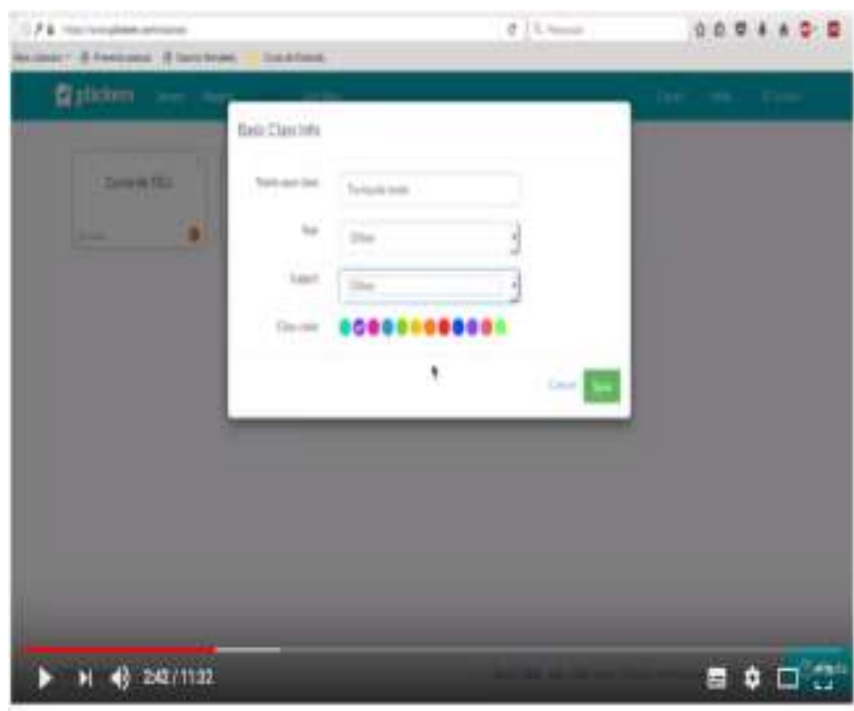

Utilzando o Plickers

1 isse nisatiantes

Fig -2: Videoclassproducedtothe workshop Technologies in theclassroom. Source: IFRN/MOODLE (2017).

Among the teachers that participated on these activities there was no resistance at all to use the Technologies as is commonly attributed to it on a common sense. This maybe demonstrates that we, the teachers, are not so far from our students considered Homo Zappiens by Veen and Vrakking[12]. Even belonging to distinct generations, the dynamism and the interest of the teachers in training were essential to finish this step of practice that evolved an activity in their classroom.

There were 15 teachers in training along the workshop, but only five finished the whole program. The other evaded, did not start or conclude the activities. The workshop was planned to be a distance course exactly to provide the flexibility that teachers needed in their schedules to study, but evasion was higher than $60 \%$. This is a negative aspect we still have to understand, how the beginning motivation of these teachers disappeared after a few weeks.

\section{THE RESEARCH RESULTS}

The research, among other data, tries to observe the seven axioms proposed by Sancho [11] to convert TICs on triggers to innovation on the answers given by the subjects. The questionnaire used presented a question that asked the 
subjects to point his degree of acceptance - using the Likert, Roslow and Murphy [7] scale - with some assertive based on Sancho's ideas.

The first proposition was: "The school where I work has an appropriate technological infrastructure that permits to establish an stimulating educational environment that promotes learning to all students." According to Sancho [11], it is essential that the whole school community continuously question itself if the school has the minimal infrastructure to stimulate the process of teaching and learning to all the students. To this assertive, 5 subjects answered I agree, 2, I totally agree and 8, I disagree. As we can see, more than $50 \%$ of the subjects believe their school does not have the appropriate infrastructure to stimulate the use of technologies in the classroom, what may be considered a great obstacle to teacher's work, even if the other axioms are (or aren't) effectively contemplated.

The second assertive was: "The curriculum of my school favors the use of TIC (Technologies of Information and Communication)." Yet according to Sancho [11], the schools must "integrate the new modes to all the students including them in all the curriculum aspects". To do this, it is necessary to question, for instance, if the curriculum needs a review to favor the use of TICs, and also to other changes. To this assertive, 5 subjects answered I agree, 1 answered I totally agree, 5 answered I disagree and 4 answered I don't know. It is important to note that a considerable number of subjects didn't know the curriculum of their school, 3 from the JoãoTibúrcio State School and 1 of the Brigadeiro Eduardo Gomes City School. It is obvious that before any change in the curriculum to favor the use of TICs, it is necessary to discuss and to socialize the curriculum in use.

The third assertive was: "My actual work condition guarantees enough time and energy for me to receive the proper training and to overview the possible educational use of TIC". The answers presented the following result: 2 subjects answered I agree, 2 answered I totally agree, 7, I disagree, 3 I totally disagree, 1, I don't know. According to Sancho [11], the use of TICs on the schools must result from the teacher's initiatives, based on a no authoritative system as the proposal of the constructive perspective. Thus, it is important that those who manage the school think how they support the teachers that try to promote the use the TICs in their classroom or try to achieve some training. It is also important that the schools that collaborated with this research are public schools and that many times, facing the national context, the management staff of the Brazilian schools cannot ease schedules to allow teacher formation, for they depend on the educational politics of each region. Sometimes this is a decision that surpasses the will of the principal and the management staff of each school. It is necessary to consider the social context, the educational project of each school, the school culture and the institutions that control education in each region.
In order for the school to stimulate the teacher's use of TICs, giving proper work condition and training, it would be necessary to ease schedules, so the teacher may have hours to plan, to receive training and to develop ideas, what generally does not occur. The disagree answers to the research's third assertive may also be based on the fact that many teachers have more than one place to work, more the one work bond, totalizing, sometimes, more than 30 hours of working per week, not including the time they spend preparing lessons, evaluating activities, tests or giving feedback. So, they do not have additional hours to create innovative methodologies.

The fourth assertive was: "The school stimulates the use of technological resources as investment on the student's abilities to acquire their own education". Among the results presented, 6 subjects answered I agree, 1, I totally agree, 4, I disagree, 4, I don't know. Sancho [11]says that, in many occasions, the school is much more worried that students pass on final tests than in the quality of the learning. As years pass by, and new theories arise, new educational defiance also emerges, and it is necessary to reflect about them. To do this, it is imperative to question the roles of schools in society and the stimuli they have to offer to the students in order to promote them as capable to use the TIC to build knowledge. More than $50 \%$ of the subjects answered they disagreed or didn't know if the school stimulated this aspect, this is a strong factor to be considered by these schools.

The fifth assertive was: “On my teacher's routine I am able to predict what a good student will learn after as a result of an educational experience". The result was: 7 answered I agree, 4 I totally agree, 2 I disagree, 2 I don't know. Sancho says that teachers must forget to base their results on the applied instruments, because it became an illusion that the pedagogical experience is based on the mere repetition of what the teachers say or display in the classroom, or the fixation exercises. It is necessary to think and to create alternatives, for example, if the student reacts different to what was expected, as well as, it is necessary to consider the background that students bring to the classroom, and how they may (and they should?) contribute to the rest of the class. As can be observed by the answers, some teachers still think they can predict the results achieved by a "good student", without questioning what a "good student" may be.

The sixth assertive was: "My classroom is a place were the students and I communicate with the participation of all". The results show 9 I agree, 4 I totally agree, 2 I disagree. Sancho [11] says that the classroom is a place of coparticipation, that is, where students and teachers interact among them and with other individuals of the community as invited specialists, for example. So, the pedagogical model proposed in a classroom must be collaborative and the answers were positive in this aspect. The subjects gave a favorable answer, and they demanded collaboration from the external community members (students and teachers of 
IFRN) and accepted them in the school and in their own classes.

The last assertive was related to the sixth: "I take into consideration the different thoughts and ways to build knowledge my students present". The results were: 8 I agree and 7 I totally agree. To Sancho [11], the main idea when we approach this aspect is that is important to question the pedagogical common sense. Sancho [11] suggests that pedagogical convictions about the logical scientific thought must be reviewed, as well as the stereotyped ideas about the students and how they learn, and also the conceptions of the scholar knowledge as a collection of stable contents. The answers of the subjects were positive to this argument, a synthesis of the answers is presented on the table 1 , below.

Table -1: Synthesis of the results of the research tool.Source: Research data.

\begin{tabular}{|l|l|l|l|l|l|}
\hline & $\begin{array}{l}\text { I } \\
\text { totally } \\
\text { agree }\end{array}$ & $\begin{array}{l}\text { I } \\
\text { agree }\end{array}$ & $\begin{array}{l}\text { I } \\
\text { don't } \\
\text { know }\end{array}$ & $\begin{array}{l}\text { I disagree } \\
\text { disagree }\end{array}$ \\
\hline $\begin{array}{l}\text { The school were I work has an appropriate technological } \\
\text { infrastructure that permits to establish an stimulating } \\
\text { educational environment that promote learning to all students }\end{array}$ & 2 & 5 & & 8 & \\
\hline $\begin{array}{l}\text { The curriculum of my school favors the use of TIC } \\
\text { (Technologies of Information and Communication) }\end{array}$ & 1 & 5 & 4 & 5 & \\
\hline $\begin{array}{l}\text { My actual work condition guarantee time and energy enough } \\
\text { for me to receive the proper training and to overview the } \\
\text { possible educational use of TIC }\end{array}$ & 2 & 2 & 1 & 7 & 3 \\
\hline $\begin{array}{l}\text { The school stimulates the use of technological resources as } \\
\text { investment on the student's abilities to acquire their own } \\
\text { education }\end{array}$ & 1 & 6 & 4 & 4 & \\
\hline $\begin{array}{l}\text { On my teacher's routine I am able to predict what a good } \\
\text { student will learn after as a result of an educational experience }\end{array}$ & 4 & 7 & 2 & 2 & \\
\hline $\begin{array}{l}\text { My classroom is a place were the students and I communicate } \\
\text { with the participation of all }\end{array}$ & 4 & 9 & & 2 & \\
\hline $\begin{array}{l}\text { I use to take into consideration that the different thoughts and } \\
\text { ways to build knowledge my students present }\end{array}$ & 7 & 8 & & & \\
\hline
\end{tabular}

It is possible to conclude, after all the results presented, that both schools that collaborated with the research need to develop the axioms presented by Sancho [11]. They need changes in their infrastructure, they need to improve the stimuli to the students and the teachers training, and even review their curriculum in order to create better spaces of formation. The lack of knowledge about the curriculum, and about how they approach the use of TIC was a factor to note and demonstrates the necessity to create moments of collective discussion and planning among the teachers.

Besides the negative aspects, it is also important to point out the role the teachers play on favoring the participation of the students in the classroom, facing the traditional and pedagogical common sense, something that is essential to a teacher that wants to assume a role of mediating the process to build knowledge. It transcends the school walls, evolves the whole community and turns into a sense of wide collaboration as it was possible to view on the development of the research and extension projects brought to school by the students and teachers from IFRN.

\section{CONCLUSION}

TICs are present on our daily lives on personal, social, economic and security aspects... Health, for example, has had great jumps in order to develop surgical procedures with the use of TICs, using video equipment, being less invasive, and promoting quick recovering. It is disturbing to notice that education does not follow the same evolution. On the other hand, it is clear that society is able to find different solutions to implement the use of TIC in the classroom, and that this is something teachers and students seek for, that may be different, innovative, stimulating new ways to build knowledge. This work tried to understand how are the obstacles to develop this use, and how the teachers conceive this use. The space was two public schools in $\mathrm{RN}$, the way to do this was integrating two projects - research and extension.

The two projects were developed on a collaborative perspective by the group of Multireference, education and language (GPMEL) from IFRN. It was necessary not only to read about the use of technologies in education, but to understand how the public education is affected for the social and political aspects. The results show that, in order to make TICs as triggers to innovation in education, it is essential to create a favorable system, that is something that surpasses the will of the individuals, that surpasses the management group of each school, cause it depends of the political decision taken place on each region and all over the country.

Sancho [11], among others, was the author that partially based the projects, and totally based the instrument assertive 
presented in this paper, for the axioms she mentioned more than ten years ago still are so important, because the reality of public schools didn't change a lot over these years. Some of the results presented reaffirm this conclusion.

Facing this reality, though, it is evident a great will for the change among the subjects. This will takes place on their overture to receive the group from IFRN in their community, collaborating to the research and allowing the development of the extension workshops. Though evasion, it is also evident the sense of welcoming when participating the workshop Technologies in the classroom.

The reality is also present in the lack of infrastructure to develop the use of technologies in the schools. Sometimes, for instance, it was necessary to use IFRN as the place to offer the workshops, as the one offered for the teachers, because the school connection with internet and the structure of the labs were not enough to develop the program. The group also provided transportation for teachers and students interested in being present to the event that ended the projects of the year.

The teacher's informal report demonstrated the interest to maintain projects into the schools, what pushes GPMEL into action, idealizing new propositions and projects every new year. There are a lot of obstacles, but the will to change is also strong, as can be seen in the following report of one of the subjects:

"[...] though the many possibilities to innovate in the classroom, we can declare that when balancing "possibilities $\mathrm{X}$ defiance" in this implementation of the new technological tools, the defiance is on the front line, unfortunately. We, teachers from public schools, compromised with the quality of modern education, will keep our battle, facing these difficulties and trying to overview changes around us, compromising with the new demands from this "virtual age" youth."

It is clear that the teachers commitment, as well as the commitment of the schools, points to new collaborative possibilities on the path to make the necessary changes on public school in Brazil in order to achieve the quality we desire and in order to use technologies better. It is expected that, even if we don't walk on the large steps we desire with other areas walking fastest - it doesn't mean we don't walk, and we walk hand in hand.

\section{ACKNOWLEDGEMENT}

We'd like to thank all those who are part of the Multireference, education and language group, teachers and students of the partner schools, and all those who directly or indirectly contributed to our experiences on the research and extension projects.
[1] Barros, D. M. V, \& Simões, P. (2014). Educação a Distância e as Novas Estratégias Pedagógicas: ferramentas da web 2.0 e estilos de aprendizagem. In: Mill, Daniel. Educação a Distância e Tecnologias Digitais. São Carlos: EDUFSCAR.

[2] Chevallard, Y. (1991).La TranspositionDidactique. Grenoble: La Penséesauvage.

[3] D’Ambrósio, U. (1999).Educação para uma sociedade em transição. Campinas: Papirus.

[4] Damiani, Magda Floriana. (2008). Entendendo o trabalho colaborativo em educação e revelando seus benefícios. Revista Educar: Curitiba: Editora da UFTPR, 12-13.

[5] IFRN.Projeto Político Pedagógico. Disponível em: http://portal.ifrn.edu.br/institucional/projeto-politicopedagogico. Accessed: 17 Mar. 2016.

[6] Kenski, Vani Moreira.Educação e Tecnologias: o novo ritmo da informação. São Paulo: Papirus, 2007.

[7] Likert, R., Roslow, S., \& Murphy, G. (1993).A SimpleandReliableMethodofScoringtheThurstoneAttit udeScales.PersPsychol 46:689-690. doi: 10.1111/j.1744-6570.1993.tb00893.x

[8] Mercado, Luis Paulo Leopoldo. Gonçalves, Monica Gomes. Tecnologia na escola: impasses para o uso do laboratório de informática na prática docente numa escola pública. In: Mercado, Luis Paulo Leopoldo. (Org.). Práticas pedagógicas com mídias na escola. Maceió: UFAL, 2013, p. 347 - 354.

[9] Morin, Edgar. (2011). Os setes saberes necessários à educação do futuro. São Paulo: Cortez.

[10] Rojo, Roxane (Org.). Escol@ conectada: os multiletramentos e as TICs. São Paulo: Parábola.

[11] Sancho, J. M. et al. (2006).Tecnologias para transformar a educação. Porto Alegre: Artmed.

[12] Veen, W., \&Vrakking, B. (2009).Homo Zappiens: educando na era digital. Porto Alegre: Artmed.

\section{BIOGRAPHIES}

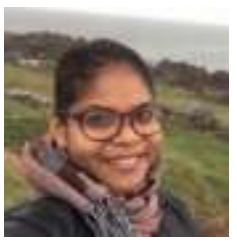

Elizama das Chagas Lemos is a $\mathrm{PhD}$ student on Systems of Information at University of Minhoand teacher of Technologies Applied to Education at IFRN. E-mail: elizama.lemos@ifrn.edu.br.

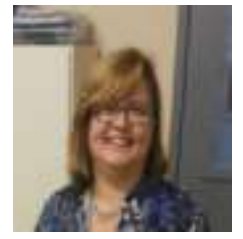

Ilane Ferreira Cavalcante is Doctor of Education and works at IFRN. It is a teacher of the Post-Graduation Program of Professional Education (PPGEP). It has academic productions on the areas of Education, Teacher's formation, Distance education, Education and technologies. E-mail: ilane.cavalcanti@ifrn.edu.br.

\section{REFERENCES}




Thalita Cunha Motta is Doctor of
Education and works at IFRN. It is a
teacher at graduation in the following
subjects: inclusive education,
educational policies e teacher's
formation.

thalita.motta@ifrn.edu.br. 